\title{
Concentration Divided by Weight
}

National Cancer Institute

\section{Source}

National Cancer Institute. Concentration Divided by Weight. NCI Thesaurus. Code C102370.

The concentration divided by weight. 